\title{
Strategic Competence of Bilingual Undergraduate Engineers in a Technical University
}

\author{
Indra Devi $\mathrm{S}^{1} \&$ Hanipah Hussin ${ }^{2}$ \\ ${ }^{1}$ Department of Languages, Centre for Languages and Human Development, Universiti Teknikal Malaysia \\ Melaka (UTeM), Malaysia \\ ${ }^{2}$ Department of Islamic Studies and Humanities, Universiti Teknikal Malaysia Melaka (UTeM), Malaysia \\ Correspondence: Indra Devi S, Department of Languages, Centre for Languages and Human Development, \\ Universiti Teknikal Malaysia Melaka (UTeM), Hang Tuah Jaya, 76100 Durian Tunggal, Melaka, Malaysia. Tel: \\ 60-16-648-4631. E-mail: indradevi@utem.edu.my
}

Received: January 16, 2015 Accepted: January 28, 2015 Online Published: June 5, 2015

doi:10.5539/ass.v11n17p144 URL: http://dx.doi.org/10.5539/ass.v11n17p144

\begin{abstract}
Today's increasingly borderless, transcultural and challenging business world, requires engineers to be communicatively competent in the oral and written form. Unfortunately, breakdowns in communication often happen, due to linguistic and psychological boundaries. In such conditions, verbal and non-verbal communication strategies also known as strategic competence helps to compensate the breakdowns. This study seeks to determine whether the Malay bilingual engineering undergraduates, who form the majority in a technical university in Malaysia, adopt the avoidance or achievement strategy dominantly in attaining a written communication goal. The instruments that were used in the study include survey questionnaires, focused group interview and Written Discourse Completion Tasks. The findings based on the Written Discourse Completion Tasks reveal that the achievement strategy which includes literal translation manifests as the most dominant strategy employed by the undergraduates. The paper concludes with a note on the significant role played by language instructors in providing optimal scaffolding. It also points towards directions for future inquiry on the need for a rigorous review of the language curriculum in technical universities so that the undergraduate engineers are able to improve their strategic competence as well as overcome the momentary inadequacy of their second language resources due to the linguistic repertoire of the Malay language which stigmatizes them as speakers of the second language.
\end{abstract}

Keywords: achievement strategy, avoidance strategy, bilingual, strategic competence, undergraduate engineers

\section{Introduction}

Rapid commoditization of education and business in today's plurilingual and competitive labour market necessitates the engineers of today to keep up with the social and linguistic realities of the global workplace. Ayokambi (2011) postulates that with the change in the landscape of the engineering and technology profession, $21^{\text {st }}$ century engineers are required to have competence beyond technical skills. They would no longer work solely in monolingual workplaces. They are rather required to work in an increasingly multilingual, borderless and competitive workplace. Thus, it is of paramount importance that they are communicatively competent. Olubimpe \& Mary (2012) define communicative competence as the ability to use the language effectively to communicate in whichever setting a person is. They add that communicative competence is not merely grammatical knowledge but knowledge of the appropriate use of language and the ability to provide appropriate answers in the right language for one's interlocutor.

This study examines the issue of communicative competence, specifically on strategic competence, a component of communicative competence (Canale \& Swain, 1980) which focuses on the pragmatic function of communication. Canale \& Swain's strategic competence refers to both verbal and non-verbal communication strategies which are used in situations like request of repetition, slower speech or clarification. According to Celce-Murcia, Dornyei \& Thurrell (1995) strategic competence refers to a speaker's ability to exploit verbal or non-verbal strategies when communication problems arise, compensating for deficiencies in other areas of competence. 
Faerch \& Kasper (1983) claim that a speaker's choice of communication strategy is influenced by his underlying behavior, that is avoidance or achievement behavior. If he opts for avoidance, then the strategies he employs would entail a change in or a reduction in the communicative goal. He gives up, omits or avoids communicating his intention. On the contrary, a learner uses the achievement strategy when he uses all his language resources to convey meaning without taking into consideration as to whether his utterances are grammatically or socially acceptable. He revises his alternative plans with the use of strategies like code-switching, generalizing, restructuring, literal translation, word coinage, paraphrase and circumlocution. Since this issue has received great attention particularly in second language learning, this research is orientated towards examining the strategic competencies of the Malay bilingual engineering undergraduates in a technical university.

Bilinguals are individuals who are able to speak two languages especially with equal or near equal fluency (Gaudart, 1996). Grosjean (1999) voices out that although some researchers have defined bilinguals as those who have native-like control of two or more languages most others contend that this kind of position is not realistic and thus this has led researchers to propose various definitions of bilingualism. Some define it as the ability to produce meaningful utterances in two or more languages, the alternate use of several languages or the command of at least one language skill like reading, writing, speaking or listening in another language.

The Merriam Webster Online Dictionary (2013) defines bilingualism as the ability to speak two languages and an individual maybe bilingual by learning languages in two different social settings eg. by learning from the family or from the second language acquired at school. Psychological studies have found that the brains of bilingual people operate differently than single language speakers (Merrit, 2013).

Recent research into the neurocognition of language suggests that bi- and multilinguals are different from monolinguals in terms of brain activation in language tasks, brain anatomy and general cognitive functioning and the differences are mainly due to the need for bilinguals to switch between languages and needing to select one language at a time while suppressing the language that is not in use (Utrecht University, 2013). Nair (2000) and Gill (2002) too exclaim that most Malaysians are bilingual and multilingual and thus bilingualism as a phenomenon is widespread in Malaysia and since the Malaysian Educational phenomenon has paved a way towards bilingualism, a research of this kind is deemed necessary. This research thus focuses on the Malaysian Malay engineering undergraduates who lay claim to a bilingual identity. These undergraduates come from schools where Malay is the official medium of instruction. The role of English in their schools is only as a school subject.

At the tertiary level, these students are required to be legitimate speakers and writers of the English language. The global domination of English within the frameworks of linguistic imperialism (Skutnabb-Kangas \& Phillipson, 2001), has indeed overlooked struggles faced by learners of English as a second language. These students who desperately need to use English in the outside world need to genuinely master the language. In this study, the bilingual Malay engineering undergraduates are often found to be influenced by the linguistic repertoire of their native language, the Malay language and the impact is that this sort of experience is often found to vilify them as speakers of the second language.

\subsection{Statement of Problem}

The researcher's interest in this study stems from the ongoing concern about local graduates low employability and failure to meet the demands of employers in terms of effective communication skills and English proficiency (Khaled, 2009). Business environments today are highly turbulent and dynamic and have caused labour markets to be increasingly competitive (Yusoff \& Indra Devi, 2012) but are these undergraduates fully equipped to persevere at their future workplace?

As observed by the researcher, despite numerous practice and exposure to writing reports, assignments, presentations and lots of other activities throughout their language courses in the university a majority of them still seem to be less-than-adequate in writing and speaking in the second language. It is often found that their reports are rife with redundancies and errors and incomplete in sentence structure and meaning. This makes their work incomprehensible. As such, there is an urgent mandatory need to investigate the matter from the root so that the skills gap can be reduced. This problem is indeed intense among Malay bilingual engineering undergraduates who form the dominant group in public higher learning institutions and specifically in technical universities.

Nor Azmi (2002) states that a major factor that is identified as contributing to low overall performance of Malay students compared to other ethnic groups is their perceived weakness in English as a second language. According to Royal Professor Ungku Aziz, the former vice-chancellor of University of Malaya, it is a 
disappointing fact that the Malay students' command of English is poorer compared to other races (The Star, 2000).

Isarji et al., (2009) state that based on scores in the English proficiency Test (EPT) and perceptions of business leaders, government officials and academic staff, Malaysian university students, in general are considered limited users of English in the productive skills namely writing and speaking. Interference of culture which includes norms, conventions and rules governing discourse is another problem faced by L2 learners. If this issue is left unchecked, the transition of these undergraduates to entry-level engineering professionals will not be worthy. Thus, it is imperative that a research of this kind which focuses basically on the writing skill is conducted.

\subsection{Objectives of the Study}

Specifically, this study aims to investigate the kind of strategy, avoidance or achievement strategy that is dominantly used by Malay bilingual engineering undergraduates in attaining a communication goal in a written discourse, Beides the study also intends to get some insights on viable measures that can be taken to improve bilingual undergraduate engineers strategic competence.

\subsection{Related Literature}

Communicative competency refers to the ability to use language effectively and to communicate in whichever setting a person is (Adekunle \& Aina, 2012) and the earliest concept of communicative competence was introduced by Dell Hymes (1972) who opposed Chomsky's concept of linguistic competence. Hymes propagated that instead of teaching grammar per say, language learners should be taught extensively on how to communicate correctly and accurately. He maintained that the notion of competence should be viewed from the sociocultural aspects of language and speakers need to be aware of the appropriate language that is to be used in the communicative events that they are involved in any particular speech community. In short, it is an ability to know when, where, how, what and in what manner to communicate (Hymes, 1972). Since then, his notion of communicative competence has been widely acknowledged, revisited and revised by English educators and scholars like Canale \& Swain (1980); Bachman (1990) and Peterwagner (2005).

Canale and Swain's notion of communicative competence (1980) model includes a modular framework of three components comprising grammatical, socio-linguistic, and strategic competence. In 1983, Canale \& Swain made some adjustments to the original model of 1980 by including the fourth component that is the discourse competence. Canale and Swain's $(1980,1983)$ communicative competence framework is the most influential work among other works in communication studies. Grammatical competence includes knowledge of grammatical language use like lexical items, rules of morphology, syntax, sentence grammar, semantics and phonology. Sociolinguistic competence refers to knowledge of how to use socio-cultural rules in different social settings and communicative functions. Discourse competence is concerned with knowledge on how to achieve cohesion in communicative situations. Finally, Canale \& Swain's strategic competence refers to both verbal and non-verbal communication strategies that are called into action to compensate breakdowns in communication and in situations where former competences fail e.g. as in request of repetition, slower speech, clarification or due to other performance variables or insufficient competence.

Tarone and Yule (1989) mentioned that strategic competence is not merely gauged by the degree of correctness but rather by the degree of success or effectiveness. This is an indication that strategic competence enables writers to select a specific communicative strategy to convey the message successfully to the reader. The present study investigates on the strategic competence as well as the type of communication strategy that is most dominantly employed by the respondents in authentic writing situations.

Cho and Clarke (2010) investigated whether repair strategies were employed by primary grade elementary students, one Indian, two Chinese and Koreans in different conversation breakdowns in an L2 classroom in Texas. Their findings indicate that various repair strategies were observed in the students' conversations. The three common strategies used by the students include specific initiation types like understanding check, partial repeat and unspecified checks. Besides, they were also found to use a wide range of non-verbal actions. Thus, Cho and Clarke (2010), elucidate that there is a need for language teachers to be aware of the types of conversational problems so as to solve their communication breakdowns.

In the context of written communication, Yarmohammedi and Seif (1992) investigated on the communication strategy of intermediate Persian learners of English. In this study, they administered three types of tasks that include writing a composition on a series of pictures, translation and the narration of a completed picture story. These tasks encompassed both the written and oral productions of the informants. The findings indicate that 
achievement strategies were employed more frequently than avoidance strategies in both the written and oral tasks. It was also found that there was greater use of the literal translation strategy in the written production of the story than in the oral production.

\section{Method}

\subsection{Setting and Samples}

The subjects involved in the study comprise 50 second year Malay bilingual engineering undergraduates each from the Faculties of Manufacturing Engineering, Mechanical Engineering, Electrical Engineering, Electronics and Computer Engineering as well as the faculty of Information and Communication Technology in a technical university, thus forming a total of 250 respondents.

\subsection{Instrumentation}

The sources of data for the research are derived primarily from the instruments as stated below:

a) Adapted version of The Language Experience and Proficiency Questionnaire (LEAP-Q): Assessing Language Profiles in Bilinguals (Marian, Blumenfeld, \& Kaushanskaya, 2007)

b) Adapted version of Written Discourse Completion Tasks (Miura, 2008)

c) Focused-Group interview questions

\subsection{Procedure}

Basically, Faerch and Kasper's (1983) Taxonomy of Communication Strategies was adapted as the framework of this study. According to Faerch and Kasper (1983), communication strategies include potential conscious plans that an individual undertakes when there is a problem in reaching a particular communicative goal and this include avoidance or achievement strategies. The respondent is identified as opting for the avoidance strategy when he is found to avoid the topic, revise his original plan or replace the intended meaning. In contrary, attempts to attain the achievement strategy are identified when they are demonstrative of achievement behavior like language transfer which includes code-switching and literal translation, besides other strategies like word coinage, paraphrase and circumlocution (Faerch \& Kasper, 1983). According to Faerch and Kasper's (1983) Taxonomy of Communication Strategies, avoidance strategy include formal reduction in terms of phonological, morphological, syntactic, lexical elements and functional reduction which includes topic avoidance, message abandonment and meaning replacement. Meanwhile achievement strategies include compensatory strategies like code-switching, interlingual or intralingual transfer, cooperative strategies, non-linguistic strategies like retrieval strategies and interlanguage-based strategies that encompass generalization, paraphrase, word coinage and restructuring. For the purpose of this study, the use of avoidance strategies that include topic avoidance, message abandonment and meaning replacement were investigated. As for achievement strategies, the use of code switching, paraphrasing, word coinage and interlingual strategies that include literal translation and circumlocution

The study adopts both quantitative and qualitative approaches in seeking answers to the research questions. In the first phase of the research, the adapted version of the LEAP questionnaire was distributed to the respondents to obtain information about their language experience and their proficiency. Quantitative analysis of the data was tabulated. In the second phase of the research, students were required to read written descriptions of four situations based on the adapted version of the Written Discourse Completion Tasks (WDCT) by Miura (2008). They were required to write spontaneously on how they would respond to the four given situations. In total, the 250 respondents submitted 1000 responses. This task was conducted to elicit the kind of strategy, avoidance or achievement strategy that they employ in responding to the situations (based on the framework by Faerch \& Kasper, 1983).

\subsection{Data Collection}

In this study, only eight communication strategies, namely, topic avoidance, message abandonment, meaning replacement, code switching, literal translation, word coinage, paraphrasing and circumlocution are investigated. Every identified strategy is plotted on a table and the percentage of each strategy is calculated based on the 1000 responses. This is followed by the calculation of the total percentage of the avoidance and the achievement strategies based on the 1000 responses. Qualitative data was obtained by interviewing a group of four language instructors for suggestions on viable measures that can be taken to improve the undergraduates' strategic competence. 


\section{Results}

The data based on the adapted version of The Language Experience and Proficiency Questionnaire (LEAP-Q) revealed that $98 \%$ or 245 of the respondents are exposed to their first language in comparison to their second language which is English. 95.2\% (238) of them preferred to read texts in Malay in comparison to English and if given a choice to communicate with a person who is equally fluent in all languages, $72 \%$ (180) preferred to communicate in the first language. $95.2 \%$ (238) of the respondents affirmed that they often speak in the first language and $79.6 \%$ (199) of them found that the English language writing skill is very challenging. The above data implies that a majority of the bilinguals favor the first language in comparison to the second language.

The findings based on the 1000 responses in the Written Discourse Completion Tasks indicated that 97.1\% (971 responses) were inclined towards the achievement strategy and $2.9 \%$ (29 responses) towards the avoidance strategy. It is also evident that $91.4 \%$ (914 responses) out of the 1000 responses on the WDC tasks included the literal translation strategy which according to Paramasivam (2009) involves a condition where the learner translates his intended meaning from one language to another. A fact to be taken note of is that the respondents' responses to some of the tasks fall under more than one strategy. The breakdown of the findings is as tabulated below:

Table 1. Number of responses and percentage of avoidance and achievement strategy employed

\begin{tabular}{llllll}
\hline Avoidance Strategy & \multicolumn{5}{c}{ Achievement Strategy } \\
\hline & Responses & Percentage & & Responses & Percentage \\
\hline Topic Avoidance & 3 & $0.3 \%$ & Code Switching & 46 & $4.6 \%$ \\
Message abandonment & 11 & $1.1 \%$ & Literal Translation & 914 & $91.4 \%$ \\
Meaning Replacement & 15 & $1.5 \%$ & Word Coinage & 24 & $2.4 \%$ \\
& & & Paraphrase & 57 & $5.7 \%$ \\
& & & Circumlocution & 233 & $23.3 \%$ \\
\hline
\end{tabular}

Focused group interview held with four language instructors resulted in several suggestions on measures that can be taken to improve the respondents' strategic competence. It had been suggested that communication strategies is made as part of the language syllabus in the university besides devising modules and coursebooks that focus on communication strategies. The language instructors have also suggested that students are provided with more language exercises, trained in the use of strategies and exposed to a wide range of interaction patterns and written dialogues as well as discuss on how these dialogues can be improved. It has also been suggested that students are prompted to define, paraphrase, explain situations in written forms, familiarized with meaningful expressions, provided language practice via computer-aided facilities like the Internet, exposed to participate in social conversations and discussions via social networking sites like Facebook or provide opinions and views in the oral and written form either face-to-face or in the online mode. Other suggested measures include the construction of a written inventory or key vocabularies that comprise technical, academic and general terms, expressions and synonymns as well as sentence building activities via collaborative group work, out-of-class activities and learning as well as exposure to exemplary speeches by Toastmasters International and other affiliated organisations.

\section{Discussion}

The research results provide a critical reflection on the strategic competence of bilingual undergraduate engineers in a technical university. It has also provided valuable insights on the type of strategy that the undergraduates dominantly employ in spontaneous written communication. These undergraduates are found to be inclined towards the achievement strategy rather than the avoidance strategy with literal translation being most popularly used. This echoes Liskin-Gasparro's report (1996) that intermediate speakers relied mostly on L1 and L3-based communication strategies which includes literal translation which is also known as foreignising. This reflects that there is inadequacy in the undergraduates' proficiency level which indulges them to seek other ways to communicate meaning in written communication. It needs to be pointed out that other achievement strategies like code-switching, word coinage, paraphrasing and circumlocution are very minimally employed in their written communication thus implying that they should be exposed to these kind of strategies in ESP-based classrooms. 
Paribakht (1985) highlights that speakers may basically employ certain communication strategies to cope with the lexical gaps in their target language but most importantly an increase in the learners' language proficiency level will provide the learner with the necessary knowledge, e.g. semantics, that they need to utilize in achieving a communication goal. This also implies that their target language proficiency needs to be developed. As advocated by Faerch and Kasper (1983), learners will be able to bridge the gap between pedagogic and non-pedagogic communication situations if they are exposed to appropriate use of communication strategies. According to Peloghitis (2006), the development of communicative competence demands a great deal of spontaneity and the ability to cope with the unexpected. Therefore, as advocated by Scarcella and Oxford (1992), written communication should not be restricted to basic patterns on prefabricated situations or topics. Instructors should rather expose the students to authentic real-life and spontaneous communication so that they have ample exposure and practice in compensating their target language deficiencies as well as enhance their written communication in the second language.

This study also shows that a very minimal number of responses $(2.9 \%)$ are inclined towards the avoidance strategy and $91.4 \%$ towards the achievement strategy thus implicating a positive note that these bilingual undergraduates are motivated to achieve their communicative goals. Herein, lies the role of ESP instructors to play a prominent role in developing the bilingual undergraduates' strategic competence. Evidence for the teachability of strategic competence is provided by research, e.g. by O'Malley (1987) which stresses that the teaching of these strategies should be embedded in the curriculum and that future research should be directed towards refining strategic training approaches. As pointed out by Jiang (2011), instructors can deduce the interactional patterns among bilingual learners by designing teaching materials and by exposing them to react to communicative situations which provide the learners with the opportunities to initiate, contribute or repair conversations.

\section{Conclusion}

As suggested by Corder (1978) and Faerch and Kasper (1983), achievement strategies contribute to successful language learning. Johnstone (1989) highlights that strategies related to achievement behavior are more frequently used as one's language confidence grows. Thus, despite the fact that a majority of the undergrads manifest on achievement strategies it is envisaged that communication strategies training need to be stressed in campuses so that undergraduates are more familiarised and are better prepared for the future workplace. This study also points towards direction for future inquiry on determining the type of strategy and skills training that can be embedded in the ESP curriculum for undergraduate engineers in technical universities. In essence, this implies that language instructors need to be more dynamic and resourceful in creating a natural environment that fosters practice in strategic competence.

\section{Acknowledgments}

This study was funded by Universiti Teknikal Malaysia Melaka (PJP/2009/PBPI(4G)-S698). We would like to express our gratitude to the university on the funding and are grateful for the cooperation and assistance received from the participating students and instructors in the collection of data.

\section{References}

Adekunle, O. O., \& Aina, M. O. (2012). Developing communicative competence in learners of English as a second language. Multidisciplinary Journal of Research Development, 18(1).

Ayokanmbi, M. F. (2011). Competencies for global engineers and technologists. Journal of Industrial Technology, 27(1).

Canale, M. (1983). From communicative competence to communicative language pedagogy. In J. C. Richards, \& R. W. Schmidt (Eds.), Language and Communication (pp. 2-27). London: Longman.

Canale, M., \& Swain, M. (1980). Theoretical bases of communicative approaches to second language teaching and testing. Applied linguistics, 1(1), 1-47. http://dx.doi.org/10.1093/applin/1.1.1

Celce-Murcia, D., \& Thurrell. (1995). Communicative competence: A pedagogically motivated model with content specification. Issues in Applied Linguistics, 6(2).

Cho, E. H., \& Larke, P. (2010). Repair strategies usage of primary elementary ESL students; implication for ESL teachers. TESL-EJ, 14(3), 1-18.

Corder, S. P. (1978). Language learner language. In J. C. Richards (Eds.), Understanding second and foreign language learning: Issues and approaches. Rowley, M.A.: Nerbury House.

Fearch, C., \& Kasper, G. (1983). Plans and strategies in foreign language communication, In C. Faerch, \& G. 
Kasper (Eds.), Strategies in interlanguage communication (pp. 20-60). London: Longman

Gaudart, H. (1996). Some Malaysian Bilingual student teachers: A profile. Journal of Multilingual and Multicultural Development, 17(2-4), 169-189. http://dx.doi.org/10.1080/01434639608666269

Gill, S. K. (2002). International Communication: English Language Challenges for Malaysia. Serdang: Universiti Putra Malaysia Press.

Grosjean, F. (1999). Individual bilingualism. In Concise Encyclopedia of Educational Linguistics. Oxford: Elsevier.

Hymes, D. (1972). On communicative competence. In J. Pride, \& J. Holmes (Eds.), Sociolinguistics: Selected readings (pp. 269-293). Harmondsworth: Penguin. http://dx.doi.org/10.1080/03075079.2011.580838

Isarji, S., Ainol, M. Z., \& Afiza, M. A. (2009). A comparative analysis of engineering students' problems in speaking and writing. Proceedings of the 2nd International Conference of Teaching and Learning. INTI University College, Malaysia.

Jiang, X. (2011). Influence of bilingualism on children's conversational skills. West Virginia University.

Johnstone, R. (1989). Communicative interaction. London: CILT. http://dx.doi.org/10.7575/aiac.alls.v.4n.1p.129

Khaled, N. (2009). Speech in Seminar on 'Enhancing Graduate Employability: Issues, Concerns and the Way Forward. Marriot, Putra Jaya. 21 July.

Liskin-Gasparro, J. E. (1996). Circumlocution, communication strategies, and the ACTFL proficiency guidelines: An analysis of student discourse. Foreign Language Annals, 29(3), 317-330. http://dx.doi.org/10.1111/j.1944-9720.1996.tb01245.x

Marian, V., Blumenfeld, H., \& Kaushanskaya, M. (2007). The Language Experience and Proficiency Questionnaire (LEAP-Q): Assessing language profiles in bilinguals. Journal of Speech, Language and Hearing Research, 50, 940-967. http://dx.doi.org/10.1044/1092-4388(2007/067)

Merriam Webster Online Dictionary. (2013).

Merritt, A. (2013). Why learn a foreign language? Benefits of bilingualism in 'The Telegraph', 19 June.

Miura, T. (2008). Strategic interaction for Japanese students. In K. Bradford Watts, T. Muller, \& M. Swanson (Eds.), JALT 2007 Conference Proceedings. Tokyo. JALT

Nair Venugopal, S. (2000). Language choice and communication in Malaysian business. Bangi: Penerbit Universiti Kebangsaan Malaysia.

Nor Azmi, M. (2002). Bilingualism and the academic achievement of Malay students. International Conference IPBA. 24-26 September 2002.

Olubimpe, O. M., Adekunle, \& Aina, M. O. (2012). Multidisciplinary Journal of research development, 18(1).

O'Malley, J. M. (1987). The effects of training in the use of learning strategies on learning English as a second language.

Paramasivam, S. (2009). Language transfer as a communication strategy and a language learning strategy in a Malaysian ESL classroom. Asian EFL Journal, 11(1). Article 10.

Paribakht, T. (1985). Strategic competence and language proficiency. Applied Linguistics, 6(2), 132-146. http://dx.doi.org/10.1093/applin/6.2.132

Peloghitis, J. (2006). Enhancing communication through the use of foreigner interviews. Journal of NELTA, $11(1-2), 47-51$.

Scarcella, R. C., \& Oxford, R. L. (1992). The Tapestry of Language Learning: The Individual in the Communicative Classroom. Boston: Heinle \& Heinle Publishers.

Skutnabb-Kangas, T., \& Phillipson, R. (2001). Linguistic human rights: overcoming linguistic discrimination. Berlin: Mouton de Gruyter.

Tarone, E., \& Yule, G. (1989). Focus on the language learner. Oxford: Oxford University Press.

The Star. (2000). Dr. M: Where have the Bumi male students gone to? 4 September: 16.

Utretcht University. (2013). The neurocognition of bilingualism and cognitive control. The Netherlands.

Yarmohammadi, L., \& Seif, S. (1992). More on communication strategies: classification, resources, frequency and underlying processes. Iral, 33(3), 223-232. http://dx.doi.org/10.1590/S1984-63982007000200008 
Yusoff, M., \& Indra Devi, S. (2012). Honing employability skills: Graduate industry experience sharing. ICERI 2012 Proceedings, $5^{\text {th }}$ International Conference of Education, Research and Innovations (pp. 2732-2738). Madrid, Spain. 19-21 November, 2012.

\section{Copyrights}

Copyright for this article is retained by the author(s), with first publication rights granted to the journal.

This is an open-access article distributed under the terms and conditions of the Creative Commons Attribution license (http://creativecommons.org/licenses/by/3.0/). 